\title{
Rural and urban poverty models on Sumatra Island
}

\author{
Candra Mustika ; Rahma Nurjanah \\ Department of Economics, Faculty of Economics and Business, Universitas Jambi, \\ Indonesia \\ *To whom correspondence should be addressed. Email: Candra.mustika@yahoo.com

\begin{tabular}{|l|l|l|l|l|}
\hline DOI: & Received: & Revised: & Accepted: & Published: \\
10.22437/ppd.v9i1.10684 & 14.10 .2020 & 27.04 .2021 & 28.04 .2021 & 30.04 .2021 \\
\hline
\end{tabular}

\begin{abstract}
This study aims to analyze rural and urban poverty on Sumatra Island, Indonesia, and its determinants. The variables tested in the model are HDI (Human Development Index), GRDP (Gross Regional Domestic Product), and per capita expenditure. The data used is panel data for the provinces on Sumatra Island in the period 2011 - 2019. The analysis tool uses a panel data regression model. The study results found that during the 2011 2019 period, the rural poverty rate on Sumatra Island was 11.68 percent, relatively higher than in urban areas, 9.22 percent. The poverty gap index and poverty severity index in rural areas are also relatively higher than in urban areas. The research results also found that the poverty level in rural areas is significantly affected by HDI, while the GRDP and per capita expenditure does not significantly affect.
\end{abstract}

Keywords: Expenditure per capita, Gross Regional Domestic Product, Human Development Index, Poverty

JEL Classification: E21, E23, I32, R10

\section{INTRODUCTION}

Sumatra Island is one of the large islands with the largest number of provinces in Indonesia. There are 10 provinces on Sumatra Island, namely the provinces of Aceh, North Sumatra, West Sumatra, Riau, Jambi, Bengkulu, South Sumatra, Bangka Belitung, Riau Islands and Lampung. With the largest area and number of provinces, Sumatra Island has a significant role in improving the Indonesian economy. Therefore, various development efforts have been carried out intensively in the provinces on the island of Sumatra.

However, the facts show that the development carried out on Sumatra Island has not improved the welfare of the people optimally. In 2019, the average poverty rate for the provinces on Sumatra Island reached 9.81 percent, above the national average of 9.22 percent.

Apart from the relatively high poverty level, poverty is also rather unequal between rural and urban areas. In 2019, the rural poverty rate reached 10.75 percent, while it was only 8.12 percent in urban areas. With a larger rural population than urban areas (the proportion of the rural population on Sumatra Island is 55.90 percent), this 
high level of rural poverty certainly has a broad impact on the welfare of the people in general Sumatra Island.

This study aims to analyze poverty models in rural and urban areas in Sumatra Island. This model is expected to provide information on the differences/similarities in the causes of poverty in rural and urban areas and at the same time become the basis for the formulation of poverty reduction policies.

The term poverty refers to the condition of a person or group of people who are unable to fulfill their minimum needs based on a certain standard of living. Poverty is a complex problem because many related factors influence it. According to Mikelsen (2003), thinking about poverty changes over time but is basically related to the inability to meet basic needs.

Lack of income and assets to meet basic needs such as food, clothing, housing, and health and education are the basic causes of poverty. Besides, poverty is also related to limited employment opportunities. Usually, those categorized as poor are unemployed, and education and health are generally inadequate (Simatupang \& Junaidi 2020). Furthermore, Kuncoro (2000) argues that poverty is caused by: 1) a pattern of resource ownership that causes an unequal income distribution. The poor have only limited and low-quality resources; 2) differences in the quality of human resources. The low quality of human resources means that their productivity will also below, which in turn will lower wages; 3 ) differences in access to capital.

Based on this and several previous studies such as Zuhdiyati \& Kaluge (2017), Biyase \& Zwane (2017), Andykha et al. (2018), Nizar et al. (2013), Rocha (2006), Azizah et al. (2018), Sangadah et al. (2020), Junaidi et al. (2020) and others, the poverty model in this study is approached through three aspects: aspects of the quality of human resources, conditions, economic growth, and expenditures to meet the needs of life. Measurement of the quality of resource sources uses the HDI indicator, economic conditions, and growth using the GDP indicator and expenditure to meet the needs of life using the per capita expenditure indicator.

\section{METHODS}

The data used in this study are secondary at the provincial level in Sumatra during the period 2011 - 2019. The data is sourced from the Central Bureau of Statistics of the Republic of Indonesia.

The data is processed descriptively to describe the characteristics of poverty between provinces and between rural and urban areas on the island of Sumatra. The characteristics of poverty use three indicators: poverty level, poverty depth index, and poverty severity index.

Furthermore, analyzing rural and urban poverty models using panel data regression models are used as follows:

$$
\begin{aligned}
& \mathrm{Y}_{1 \mathrm{it}}=\beta_{0}+\beta_{1} \mathrm{HDI}_{\mathrm{it}}++\beta_{2} \mathrm{GRDP}_{\mathrm{it}}+\beta_{3} \mathrm{PP}_{\mathrm{it}}+\varepsilon_{\mathrm{it}} \\
& \mathrm{Y}_{2 \mathrm{it}}=\beta_{0}+\beta_{1} \mathrm{HDI}_{\mathrm{it}}++\beta_{2} \mathrm{GRDP}_{\mathrm{it}}+\beta_{3} \mathrm{PP}_{\mathrm{it}}+\varepsilon_{\mathrm{it}}
\end{aligned}
$$

Where:

$\mathrm{Y}_{1} \quad$ : Rural poverty rates

$\mathrm{Y}_{2} \quad$ : Urban poverty rates 


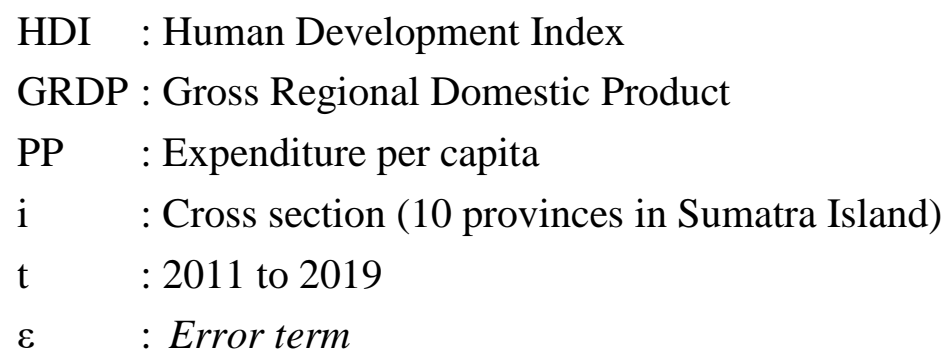

\section{RESULT AND DISCUSSION}

\section{Poverty in rural and urban areas in Sumatra Island}

At the macro level, the poverty level of an area describes the percentage of the population with per capita expenditure below the poverty line. Other measures of assessing poverty are the poverty gap index and the poverty severity index. The poverty gap index is a measure of the average expenditure gap of each poor person against the poverty line. The higher the index value, the farther the population's average expenditure is from the poverty line. The poverty severity index provides an overview of the distribution of expenditure among the poor. The higher the index value, the higher the expenditure inequality among the poor.

The average poverty rate, poverty gap index, and poverty severity index for provinces in Sumatra Island during the 2011 - 2019 period are shown in Table 1.

Table 1. Average poverty rates, poverty gap index, and poverty severity index for provinces in Sumatra Island, 2011 - 2019

\begin{tabular}{lrrrrrr}
\hline & \multicolumn{3}{c}{ Rural } & \multicolumn{3}{c}{ Urban } \\
\cline { 2 - 7 } Province & $\begin{array}{r}\text { Poverty } \\
\text { rate }\end{array}$ & $\begin{array}{r}\text { Poverty } \\
\text { gap index }\end{array}$ & $\begin{array}{r}\text { Poverty } \\
\text { severity } \\
\text { index }\end{array}$ & $\begin{array}{r}\text { Poverty } \\
\text { rate }\end{array}$ & $\begin{array}{r}\text { Poverty } \\
\text { gap index }\end{array}$ & $\begin{array}{r}\text { Poverty } \\
\text { severity } \\
\text { index }\end{array}$ \\
\hline Aceh & 19.45 & 3.57 & 0.97 & 11.14 & 1.76 & 0.42 \\
North Sumatra & 10.24 & 1.82 & 0.49 & 9.74 & 1.60 & 0.41 \\
West Sumatra & 8.26 & 1.20 & 0.27 & 5.74 & 0.90 & 0.21 \\
Riau & 8.78 & 1.34 & 0.33 & 6.49 & 0.92 & 0.20 \\
Jambi & 7.19 & 1.01 & 0.22 & 10.66 & 1.67 & 0.44 \\
South Sumatra & 13.72 & 2.22 & 0.56 & 12.96 & 2.12 & 0.54 \\
Bengkulu & 16.77 & 2.77 & 0.71 & 16.43 & 2.88 & 0.75 \\
Lampung & 15.56 & 2.50 & 0.61 & 10.21 & 1.57 & 0.37 \\
Bangka Belitung & 7.10 & 0.94 & 0.20 & 3.17 & 0.41 & 0.08 \\
Riau Islands & 9.68 & 1.13 & 0.25 & 5.70 & 0.83 & 0.21 \\
\hline Average & 11,68 & 1,85 & 0,46 & 9,22 & 1,47 & 0,36 \\
\hline
\end{tabular}

Based on Table 1, it can be seen that on average during the $2011-2019$ period, the rural poverty rate in the provinces on Sumatra Island reached 11.68 percent, while in urban areas, it was only 9.22 percent. Except for Jambi Province, the rural poverty rates in the provinces in Sumatra Island are relatively higher than those in urban areas.

In general, it can be argued that the depth index and severity index of rural poverty are also relatively higher than in urban areas. It can be interpreted that in addition to the high level of poverty, expenditure inequality (by poverty line and among the poor) in rural areas is relatively higher than in urban areas. 


\section{Rural poverty model in Sumatra Island}

Based on the Chow test and Hausman test, the random effect model is obtained as the best model in analyzing rural poverty on the island of Sumatra Island. The rural poverty model is given in Table 2 .

Table 2. An estimated model of rural poverty in Sumatra Island

\begin{tabular}{|c|c|c|c|c|}
\hline \multicolumn{5}{|c|}{$\begin{array}{l}\text { Method: Pooled EGLS (Cross-section random effects) } \\
\text { Swamy and Arora estimator of component variances }\end{array}$} \\
\hline Variable & Coefficient & Std. Error & $\mathrm{t}$-Statistic & Prob. \\
\hline $\mathrm{C}$ & 34.41419 & 5.985277 & 5.749807 & 0.0000 \\
\hline HDI? & -0.324703 & 0.093706 & -3.465134 & 0.0008 \\
\hline GRDP? & $-1.04 \mathrm{E}-06$ & $5.08 \mathrm{E}-06$ & -0.204886 & 0.8381 \\
\hline PP? & $1.79 \mathrm{E}-06$ & $1.09 \mathrm{E}-05$ & 0.163780 & 0.8703 \\
\hline \multicolumn{5}{|l|}{ Random Effects (Cross) } \\
\hline Aceh--C & 7.686607 & & & \\
\hline _North Sumatra--C & -1.166346 & & & \\
\hline _West Sumatra--C & -3.265568 & & & \\
\hline _Riau--C & -2.166946 & & & \\
\hline Jambi--C & -4.739286 & & & \\
\hline _South Sumatra--C & 1.471280 & & & \\
\hline _Bengkulu--C & 4.656164 & & & \\
\hline _Lampung--C & 3.080188 & & & \\
\hline _Bangka Belitung--C & -4.874291 & & & \\
\hline \multirow[t]{3}{*}{ _Riau Islands--C } & -0.681804 & & & \\
\hline & \multirow{2}{*}{\multicolumn{2}{|c|}{ Effects Specification }} & & \\
\hline & & & S.D. & Rho \\
\hline Cross-section random & & & 4.898243 & 0.9704 \\
\hline Idiosyncratic random & & & 0.855575 & 0.0296 \\
\hline \multicolumn{5}{|c|}{ Weighted Statistics } \\
\hline R-squared & 0.276908 & Mean dependent var & & 0.678878 \\
\hline Adjusted R-squared & 0.251684 & S.D. dependent var & & 0.974777 \\
\hline S.E. of regression & 0.843233 & Sum squared resid & & 61.14964 \\
\hline F-statistic & 10.97790 & Durbin-Watson stat & & 0.699111 \\
\hline $\operatorname{Prob}($ F-statistic) & 0.000004 & & & \\
\hline
\end{tabular}

The $\mathrm{F}$ test shows that simultaneous HDI, GRDP, and per capita expenditure significantly affect rural poverty levels in Sumatra Island. Furthermore, based on the coefficient of determination, it shows that $27.69 \%$ of changes in the level of rural poverty in Sumatra Island are influenced by HDI, GRDP, and per capita expenditure.

Even so, only partially HDI has a significant effect while GRDP and PP have no significant impact on urban poverty in Sumatra Island. The coefficient value shows that an increase of 1 percent in HDI will reduce the poverty rate by 0.32 percent.

\section{Urban poverty model in Sumatra Island}

Based on the Chow test and Hausman test, the random effect model is obtained as the best model in analyzing urban poverty on the island of Sumatra. The urban poverty model is given in Table 3 .

The F test shows that simultaneous HDI, GRDP, and per capita expenditure significantly affect urban poverty levels in Sumatra Island. Furthermore, based on the 
coefficient of determination, it shows that $62.76 \%$ of changes in the level of urban poverty in Sumatra Island are influenced by HDI, GRDP, and per capita expenditure.

Tabel 3. An estimated model of urban poverty in Sumatra Island

\begin{tabular}{|c|c|c|c|c|}
\hline \multicolumn{5}{|c|}{$\begin{array}{l}\text { Method: Pooled EGLS (Cross-section random effects) } \\
\text { Swamy and Arora estimator of component variances }\end{array}$} \\
\hline Variable & Coefficient & Std. Error & t-Statistic & Prob. \\
\hline $\mathrm{C}$ & 43.48391 & 4.212359 & 10.32294 & $\overline{0.0000}$ \\
\hline HDI? & -0.495925 & 0.065115 & -7.616184 & 0.0000 \\
\hline GRDP? & $7.84 \mathrm{E}-07$ & $3.58 \mathrm{E}-06$ & 0.218887 & 0.8273 \\
\hline PP? & $2.60 \mathrm{E}-06$ & 7.43E-06 & 0.350423 & 0.7269 \\
\hline \multicolumn{5}{|l|}{ Random Effects (Cross) } \\
\hline _Aceh--C & 2.008992 & & & \\
\hline _North Sumatra--C & 0.340648 & & & \\
\hline _West Sumatra--C & -3.124625 & & & \\
\hline Riau--C & -2.231430 & & & \\
\hline _Jambi--C & 1.193441 & & & \\
\hline _South Sumatra--C & 2.710256 & & & \\
\hline _Bengkulu--C & 6.925482 & & & \\
\hline _Lampung--C & -0.243588 & & & \\
\hline _Bangka Belitung--C & -6.171987 & & & \\
\hline \multirow[t]{3}{*}{ _Riau Islands--C } & -1.407189 & & & \\
\hline & \multirow{2}{*}{\multicolumn{2}{|c|}{ Effects Specification }} & & \\
\hline & & & S.D. & Rho \\
\hline Cross-section random & & & 4.168383 & 0.9810 \\
\hline \multirow[t]{2}{*}{ Idiosyncratic random } & & & 0.580826 & 0.0190 \\
\hline & \multicolumn{3}{|c|}{ Weighted Statistics } & \\
\hline R-squared & 0.627636 & Mean dependent var & & 0.428146 \\
\hline Adjusted R-squared & 0.614647 & S.D. dependent var & & 0.922959 \\
\hline S.E. of regression & 0.572944 & Sum squared resid & & 28.23073 \\
\hline F-statistic & 48.31900 & Durbin-Watson stat & & 1.022762 \\
\hline $\operatorname{Prob}($ F-statistic) & 0.000000 & & & \\
\hline
\end{tabular}

Even so, as well as the rural poverty model, only partially HDI has a significant effect while GRDP and PP have no significant impact on urban poverty in Sumatra Island. The coefficient value shows that an increase of 1 percent in HDI will reduce the poverty rate by 0.49 percent.

\section{Discussion}

Poverty on Sumatra Island, both in urban and rural areas, is significantly affected by HDI. These results are in line with poverty models from various previous research results such as Zuhdiyati \& Kaluge (2017) in their research on 33 provinces in Indonesia, Andykha et al. (2018) in Central Java Province, and Susanti (2013) in West Java Provincie.

Dartanto and Nurkholis (2013) found that the dynamics of poverty in Indonesia are determined by education and health (as an indicator of HDI). This linkage of education to poverty was also found by Biyase \& Zwane (2017) and Maloma (2016) in South Africa, Garza-Rodriguez (2015) in Mexico, Hyder \& Sadiq (2010) in Pakistan, and Alifah et al. (2020) in West Sumatra Province.

GRDP or economic growth does not have a significant effect on poverty. It is also 
supported by previous studies, including Zuhdiyati \& Kaluge (2017), Alifah et al. (2020), and Prasad (1998) in Fiji. However, the results of this study are different from those of Nizar et al. (2013), Hasan \& Quibria (2002), Rusdanti \& Sebayang (2013), Andykha et al. (2018), and Barreto (2005). They found a significant influence between economic growth (GDP) on poverty levels.

Per capita expenditure does not have a significant effect on poverty. Previous studies also supported it, including Zudiyati \& Kaluge (2017) and Supriaman (2020). However, the results of this study are different from the findings of Rocha (2006), Azizah et al. (2018), Sangadah et al. (2020), who found a significant influence between expenditure per capita and poverty.

HDI is a determining factor for poverty in both rural and urban areas, which implies that human resource development is a key factor in poverty alleviation. The acceleration of economic development without being followed by the acceleration of human resource development will not be able to eradicate poverty fundamentally.

Furthermore, the fact that GDP does not significantly affect the poverty level shows that economic growth has not been enjoyed equally by all levels of society, especially the poor. Likewise with the expenditure per capita. The increase in expenditure does not reflect an increase in the income of the poor. It is estimated that the increase in expenditure is due more to the increased consumption of middle and upper-income people.

\section{CONCLUSIONS AND RECOMMENDATIONS}

\section{Conclusions}

The average level of poverty in rural areas on Sumatra Island is relatively higher than in rural areas. This high poverty level in rural areas is also followed by a relatively higher expenditure inequality (by poverty line and among the poor) compared to urban areas.

Poverty in Sumatra Island, both in rural and urban areas, is influenced by the quality of human resources (HDI). At the same time, the GRDP and per capita expenditure does not have a significant effect. It implies that the quality of human resources is a key factor in poverty alleviation. Economic development will only be successful in alleviating poverty if carried out simultaneously with human resource development.

\section{Recommendations}

In formulating poverty alleviation policies, the government must focus more on development that is oriented towards improving the quality of human resources and the productivity of society. In addition, the development that is being carried out should also be able to increase the distribution of welfare both among community groups and between regions.

\section{REFERENCES}

Alifah, A. Yozza, H. \& Asdi, Y. (2020). Faktor-Faktor yang Mempengaruhi Kemiskinan di Kota/Kabupaten Provinsi Sumatera Barat dengan Menggunakan Analisis Regresi Panel. Jurnal Matematika UNAND, 9(1), 53 - 61

Andykha, R., Handayani, H.R. \& Woyanti, N. (2018). Analisis Pengaruh PDRB, 
Tingkat Pengangguran, dan IPM terhadap Tingkat Kemiskinan di Provinsi Jawa Tengah. Media Ekonomi dan Manajemen, 33(2), 113-123

Azizah, E.W., Sudarti, S. \& Kusuma, H. (2018). Pengaruh Pendidikan, Pendapatan Perkapita dan Jumlah Penduduk Terhadap Kemiskinan Di Provinsi Jawa Timur. Jurnal Ilmu Ekonomi, 2(1), 167-180

Barreto, F.A., 2005. Crescimento Econômico, Pobreza e Desigualdade: o que sabemos sobre eles? UFC/CAEN/Laboratório de Estudos de Estudos da Pobreza, Fortaleza (Série Ensaios sobre a Pobreza)

Biyase, M., \& Zwane, T. (2018). An Emprical Analysis of the Determinants of Poverty and Household Welfare in South Africa. Journal of Developing Areas, 52(1), 115130.

Dartanto, T. \& Nurkholis. (2013) The Determinants Of Poverty Dynamics In Indonesia Evidence From Panel Data "Bulletin of Indonesian Economic Studies, 49(1), 6184

Garza-Rodriguez, J. (2015). The Determinants of Poverty in Mexico. MPRA Paper No. 65993. Available at https://mpra.ub.uni-muenchen.de/65993/

Hasan, R. \& Quibria, M.G. (2002). Poverty and Pattern of Growth. Economics and Research Department - ERD Working Paper series. 18. Manila: Asian Development Bank.

Hyder, A. \& Sadiq, M. (2010). Determinant of Poverty in Pakistan. Hambur Review of Social Sciences, 4(3), 193-213

Junaidi, J., Amir, A., \& Amril, A. (2020). Analysis of the Socio-EconomicDemographic Characteristics of the Family, Social Capital and Economic Coping Strategy in Increasing Food Security for Urban Poor Households in Jambi Province, Indonesia. Dirasat, Human and Social Sciences, 47(2), 408-424

Kuncoro, M. (2000). Ekonomi Pembangunan: Teori, Masalah dan Kebijakan. Yogyakarta: UPP AMP YKPN.

Maloma, I. (2016). The Socioeconomic Determinants Of HouseHold Poverty Status in a low-income Settlement in South Africa. International Journal of Social Science dnd Humanity Studies, 8(2), 122-131

Mikkelsen, B. (2003). Metode Penelitian Partisipatoris dan Upaya-Upaya Pemberdayaan. Jakarta: Yayasan Obor Indonesia

Nizar, C. Hamzah, A., \& Syahnur, S. (2013). Pengaruh Investasi dan Tenaga Kerja Terhadap Pertumbuhan Ekonomi serta Hubungannya terhadap Tingkat Kemiskinan di Indonesia. Jurnal Ilmu Ekonomi Pasca Sarjana Universitas Syiah Kuala. 1(2), 1-8

Prasad, B. C. (1998). The woes of economic reform: poverty and income inequality in Fiji. International Journal of Social Economics, 25(6/7/8), 1073-1094.

Rocha, S. (2006). Pobreza no Brasil. Afinal de que se trata?, 3 ed. FGV, Rio de janeiro.

Rusdanti, L. \& Sebayang, L.K. (2013). Faktor-Faktor yang Mempengaruhi Tingkat Kemiskinan di Jawa Tengah. Jurnal Economia, 9(1), 1-9

Sangadah, S.K., Laut, L.T. \& Jalunggono, G. (2020). Pengaruh Faktor-Faktor Penyebab Kemiskinan di Kabupaten Kebumen Tahun 2009-2018. Dinamic: Directory Journal of Economic, 2(1), 229 - 243

Simatupang, J. \& Junaidi, J. (2020). Poor Households Expenditure for Preventive and 
Curative Health Needs. International Journal of New Economics and Social Sciences, 1(11), 197-208

Supriaman, S. (2020). Analisis Faktor-Faktor Yang Mempengaruhi Kemiskinan Di Provinsi Nusa Tenggara Barat, Indonesia. Esa Jurnal Ekonomi Syariah, 3(1), 135 $-159$

Susanti, S. (2013). Pengaruh Produk Domestik Regional Bruto, Pengangguran dan Indeks Pembangunan Manusia terhadap Kemiskinan di Jawa Barat dengan Menggunakan Analisis Data Panel. Jurnal Matematika Integratif, 9(1), 1-18

Zuhdiyaty, N. \& Kaluge, D. (2017). Analisis Faktor-faktor yang mempengaruhi kemiskininan di Indonesia selama lima tahun terakhir (Studi kasus 33 Provinsi). JIBEKA, 11(2), 27-31.

(C) 2021 by the authors. Licensee JPPD, Indonesia. This article is an open-access article distributed under the terms and conditions of the Creative Commons Attribution (CC BY) license (http://creativecommons.org/licenses/by/4.0/). 